\title{
Technological Effort and Innovative Performance in Brazilian Bio Companies
}

\author{
Ana Lúcia Magri Lopes',Valéria Maria Martins Judice²
}

\begin{abstract}
This work had the objective to analyze technological efforts and to evaluate the innovative performance of biotechnology and biosciences companies in Belo Horizonte, (MG, Brazil). In order to reach these objectives, a survey was undertaken in eight companies. Data collection was undertaken with an existent questionnaire found in the literature of sciencebased companies, therefore a replication process was carried out The analyses of collected information have indicated that the companies have expended substantial technological efforts oriented towards internal R\&D in their majority. A minority of companies have expended less expressive technological efforts related to technology acquisition through external sources. The internal R\&D activities observed are more directed to product than to process innovation. As for innovative performance, the results have evidenced that it is concentrated in the minority of companies and the number of substantially new products is superior to the number of technologically improved products launched in the market.
\end{abstract}

Keywords: Brazil; technological effort; innovative performance; biotechnology; bio companies; biosciences; belo horizonte.

\footnotetext{
I Faculdade Novos Horizontes, Unidade Santo Agostinho, Rua Alvarenga Peixoto, 1270, 30180-I21, Belo Horizonte, MG, Brazil. Phone number: 55 3293-7000 Cel number 55 3I 85 II-248I.Email:ana.lopes@unihorizontes.br

2 Universidade Federal de São João del-Rei, UFSJ, Departamento de Ciências Administrativas e Contábeis, DECAC, Campus Tancredo Neves, CTAN, Avenida Visconde de Rio Preto, S/N, Colônia do Bengo, 33360-30I São João del-Rei, MG, Brazil, Cel Number: 55 32 $8874-$ 4027. Email: valeriajudice@ufsj.edu.br
} 


\section{Introduction}

Biotechnology and bioscience industries are evolving areas which have initiated production in the late 1970s. They have doubled their size by the 1990s (Ernst \&Young, 2000) and currently are one of the most intensive R\&D industries. According to the Biotechnology Industry Organization (BIO, 2008), investments have tripled from 1996 to 2006, reaching \$27. I billion. In face of 2008 global crisis, investment levels stayed robust, as companies in the US, Europe and Canada raised US $\$ 5.8$ billion in 2009 and U\$5.9 billion in 2010 (Ernst \& Young, 201I). According to Pisano (2006), the bio industry has attracted more than $\$ 300$ billion in capital in its thirty years of life.

In Brazil, the productive base of biotechnology companies includes several economic sectors, as agriculture, human and animal health, industrial inputs (enzymes), environment and bio-energy. Brazil is currently seen as a leading position in agricultural biotechnology and is the second largest biotech crop cultivating country, with $17 \%$ of the world's biotech acreage (Ernst \& Young, 20II). Other leading area in Brazil is biofuels, with the world's largest sugarcane-based ethanol market and investments of US $\$ 5.6$ billion in biofuel production in 2010 (Ernst \& Young, 20II).

According to Fundação Biominas (2007, 2009), Brazil has a total of I8I companies, of which, 7I are Biotechnology companies and 110 are Life Science (or Bioscience). The States of Minas Gerais (MG) and São Paulo (SP) concentrate $73 \%$ of companies, each one of them with 66 biotech / life sciences companies.

It is recognized that advances in biotechnology and bioscience industries become increasingly more important, as they impact socio-economic development and particularly on population life quality standards. In spite of all these potentials, the average rate of technological innovation in all industrial sectors in Brazil is still low, as pointed out by the Technological Innovation Survey carried out in the Pintec study of 2008 (IBGE, 2008). In it the Brazilian innovative index' has increased from $35,52 \%$ (1998-2000) to 38,11\% (2006-2008).
Technological innovation and economic development relationships have been emphasized by the classical literature (Schumpeter, 197I), as well as by several authors (Barbieri and Alvares, 2003, Correia, et al., 2005; Arruda, et al., 2006). However, in Brazil, Arruda, et al., (2006) have shown that Brazilian private companies R\&D investment represents an average of $0.64 \%$ of innovation sales, whereas the amount of European private companies' R\&D investments reached $6.5 \%$ of sales, and in the United States that share was $5 \%$.

In view of the innovation and development relationships, according to the literature and, on the other hand, the empirically observed drawbacks in innovation investment by Brazilian firms (Arruda et al., 2006, IBGE, 20I0), also taking into account the relevant social and developmental benefits resulting from innovations in the chosen field of investigation, biotechnology, the research questions of the present study are:

Can Brazilian biotechnology and life science companies be considered innovative? How intense is the technological effort directed to internal R\&D focused activities and what results do firms actually get from these actions?

In the aim of answering these questions, the main goal of this study is to analyze the "technological effort" carried out by Brazilian biotechnology and biosciences companies and their achieved innovative performance, within a defined period of time. In order to do that, three specific objectives established are: (I) to characterize the biotechnology and bioscience companies in the city of Belo Horizonte (MG), (2) to identify and to measure the firms' technological efforts (3) to assess the innovative performance of firms, as measured by R\&D expenditures and results.

In order to meet these objectives, a descriptive study of quantitative nature (Collis and Hussey, 2005) was carried out with eight biotechnology and bioscience companies located in the city of Belo Horizonte, state of Minas Gerais, an area of company concentration (Biominas, 2007, 2009), within the period from 2006 to 2008.

'The innovation index is the ratio between the number of companies that reported having at least one innovation in the considered period and the total number of surveyed companies. 
The paper is divided into seven sections, including the introduction. The second section presents the theoretical framework, the third section highlights the scope and context of the study, the fourth section describes the methodological approach, the fifth section describes the obtained results, followed by the sixth section with the discussion and the seventh section with concluding remarks.

\section{Theoretical framework 2.I Technology effort}

The concept of technological effort used in this study is based in Rieg and Alves Filho (2003). It refers to a methodology developed by Sociedade Brasileira de Estudos de Empresas Transnacionais ${ }^{2}$, SOBEET (2000) to measure the amount of resources companies devote to R\&D activities. According to SOBEET (2000), the technological effort of a particular company can be measured by the amount of resources this company invests in R\&D and acquisition of technological capabilities. The term technological capability is defined by SOBEET as expenditures related to technological support to R\&D as, for example, trademarks and patents, researcher training, equipment maintenance, technology acquisition from outside sources.

Although R\&D and technological capabilities are not exclusive indicators used by organizations in their innovation activities, according to Santana, et al., (2003), they are part of the elements that increase the enterprise competitiveness, as well as the tactics adopted by companies at any given time and place. In addition, the company develops the creative work on a systematic basis to increase the stock of knowledge and use it in new applications (OECD, 2005).

\section{I.I In-house, structured and semi-structured R\&D}

Santana et al., (2003, p. 156) see the terms of "research and development" (R\&D) as related to a "body of knowledge, skills and techniques that the company develops internally or in partnership, aiming at creating new or improving already existent knowledge". For these authors, this concept encompasses both the activities of basic and applied research.

\footnotetext{
${ }^{2}$ Brazilian Society of Studies on Transnational Companies.
}

Rieg and Alves Filho (2003) point out that basic research is applied to scientific development and aimed at discoveries that can bring long term gains for the company, while applied research is oriented towards developing specific knowledge, guided to products or process development that can be commercialized by the company in the short term.

The large companies invest both in basic as well as in applied research, and are often characterized by a significant technological effort, by its own R\&D structure and in-house research. In contrast, small-sized enterprises are mostly oriented to applied research, due to the high expenses of basic research investments. Additionally, they often have semi-structured R\&D departments (Pinho, 2006). In Rieg and Alves Filho (2003) view (p. 295), this means that the R\&D activities of small businesses "are carried out sporadically by different groups of people, and usually are developed in an attempt to meet the immediate needs of customers. The R\&D activities are also performed to complement technology acquisition from external sources. For example, the company may acquire some technology that needs to be decoded and/or disembodied, then, the R\&D activities will be developed for this purpose. Sporadic R\&D activities are denominated semi-structured R\&D."

Thus, the semi-structured R\&D process seems to be closely related to the small-sized companies. Strong evidence for this, according to Pinho (2006), is that structured R\&D grows according to company size, reaching the majority of firms with over 20 employees and practically all of those with more than 100 employees.

Pinho (2006) believes, however, that the degree of R\&D structuring does not follow any clearly defined industry pattern. Nor it is clear the relationship between R\&D structuring and company growth rates, as measured by sales increase. In any case, one should be cautious with this interpretation, since information on growth is available for small number of companies. 


\subsection{2 - Non structured R\&D}

A growing number of companies seek to increase the technological resources oriented to new or improved product and process development. However, according to Rieg and Alves Filho (2003), these companies have generally been unable to consistently direct towards these purposes significant investments associated with a complex set of required resources and expertise. Therefore, and because the results of in-house R\&D activities are generally uncertain, companies often seek outside sources of technology. These include three main types, namely: (I) licensing, (2) strategic alliances, (3) technology purchasing and hiring from other companies, universities and research centers.

\section{I.2.I - Licensing}

Through licensing, a company sells the rights on use of a patent (which protects a product, technology or aggregate manufacturing process) or to a trademark (which protects the product name) to another company in exchange for a fee or payment of royalties (patent rights) (Jeannet and Hennessey, 1992). In short, the licensing is an agreement between two parties, one of which has property rights on technology, process or information that has been developed, while the other party makes use of that technology (or process information) paying any other specific sum to the licensor in exchange for permission to use. Generally, the object of licensing is protected by a patent and can be copied by the licensing granting (Rieg and Alves Filho, 2003, p. 256).

\subsubsection{2 - Strategic alliances}

Strategic alliances can be characterized as organizational conformations which are able to gather in a participatory mode, individuals, institutions, universities, governmental organizations and research centers, competing or not around goals and /or common themes which are unlikely to be achieved in isolation (Lambe and Spekman, 1997, Hitt, et al., 2005).

In the literature, diverse models of relationships structuring are found within the context of strategic alliances, such as joint ventures, partnerships, consortia, clusters, cooperative agreements, franchising, virtual organization, horizontal integration, flexible business networks, among others. Some authors differentiate strategic alliances from corporate networks, but an important thing is to understand that strategic alliances are nothing more than union of autonomous companies towards a common goal, thus sharing elements of the value chain (Porter, 1989).

\section{I.2.3 - Technology purchasing and contracting}

Several external sources of technology can provide companies access to a wide range of technological capabilities, essential for new or improved products and process development, balancing weaknesses of the R\&D activities and accelerating the development and commercializing of new products (Zahra and Bogner, 1999). It has been observed that in developed countries, R\&D expenditures tend to be more private than public, whereas in less developed or emergent countries, by contrast, the private sector tends to be conservative and to believe that it is easier to buy than to develop technology (Correia, et al., 2005).

Bearing in mind the magnitude of what is commonly known as "technological effort", common business problems of developing/emergent countries become apparent. In these countries, innovation activities are mostly related to the dissemination, adaptation and improvements of existing technologies. As a rule, these activities are not developed in formally structured R\&D departments, but through other types of innovation efforts.

\section{2 - Technological capabilities}

According to Pavitt (1990), "technological capability" is the product of technological learning or the accumulation of learning throughout the process by which resources to generate and manage technical change are raised or strengthened, taking into account the market and involved actors.

As for Cohen and Levinthal (1989), the process of technological learning requires an ability to assimilate technology from within the organization (absortive capacity) which is rooted in two important elements: (I) existing knowledge base and (2) intensive effort in R\&D. The first concerns intrinsic organization knowledge, while the second refers to the commitment of the organization to pursue activities to assimilate and internalize technological and organizational expertise. 
Thus, the technological learning in the company can be seen as an assimilation process which produces and disseminates new knowledge.

\subsection{Innovative performance}

The innovative performance can be defined as the result of technological efforts carried out by companies and it can be understood as decision-making processes taken by firms related to resources and technological capabilities use, acquisition and development (Zahra and Bogner, 1999). Innovative performance includes technological innovation of processes and commercially viable products, organizational innovations also market and marketing innovations. Indeed, the innovative performance is an important dimension of analysis of corporate performance, particularly to companies in technologically dynamic environments in which products life-cycles are short due to the constant demand for innovation by consumers, as well as technological innovation processes are leveraged by new technological and scientific knowledge (Fiates and Schneider, 1998), as is the case of biotechnology.

According to Quadros, et al., (1999), a company can evaluate its innovative performance by the number of technologically modified products and processes resulting from technological effort expenses and also by the revenue shares due to the commercializing of these technologically modified products.

In this article, the innovative performance is related to technology innovation in processes and commercially viable products resulting from technological efforts expended by companies. Products and processes innovations are here understood as the introduction of new products or production processes in the company or the technological modification of already existent products or processes (SOBEET, 2000).

To Suzigan (1992), innovative performance is related to: (a) the amount of product and process innovations of significant incremental and radical (new) nature; (b) to the share of revenues derived from new and improved products and processes.

\section{Scope of the study}

\section{I Biotechnology e Bioscience industry in Minas Gerais and Belo Horizonte}

According to Biominas (2007, 2009), Brazil has I8I bio companies. Minas Gerais has 66 bio companies (21 biotechnology and 45 bioscience companies) and the city of Belo Horizonte (the state capital) selected for the study, has 25 bio companies (II biotechnology and 14 bioscience companies).

For the Brazilian Service of Support to Micro and Small Enterprises (SEBRAE, 2006), the biotechnology and bioscience companies in Belo Horizonte deliver a substantial number of products and services to Brazil and abroad. The city is seen as one of the most promising bio poles in national terms. In the area of human health, Belo Horizonte stands out for making heart valves, molecular diagnostic tests that incorporate high sensitivity at low cost and several other products. In animal health stand vaccines and medicines and in animal breeding, advanced embryo transfer and molecular marking. In the environmental area it is found much experience in consulting, engineering in waste treatment and use of bioprocesses to waste recovery (SEBRAE, 2006).

\section{Methodology}

A survey was carried out with nine (9) companies in the biotechnology / biosciences companies located in Belo Horizonte, Minas Gerais. The survey was conducted through a questionnaire (replication of the same instrument used by Rieg and Alves Filho, 2003) which was submitted to the co-owners, directors or managers of the companies. The companies were selected from a directory of companies from Biominas. Twenty-one questionnaires were send and the return rate after three follow-up rounds was $43 \%$. One of the companies was eliminated because it was a nanotechnology company. Thus, eight companies (32\% of population) were considered in the analysis (38\% return rate). The data was collected, tabulated and analyzed using descriptive statistics. 


\section{Results 5.I Company characteristics}

The general characteristics of the companies surveyed were age, size and business segment. For the first characteristic, it was evidenced that 5 companies (E2, E3, E4, E7 and E8) accounting for $62.5 \%$ of the total, have been for more than eleven years in the market. This information shows the maturity of the bio companies interviewed, and can be interpreted as a sign of consolidation in this sector. Two companies (EI and E5) are aged between 6 and 10 years, while only one company (E6) has a maximum of five years of age.

The second characteristic refers to the segments of activity prevailing in these companies, comprising three categories, namely: health, mixed (multi-action segments) and environment. Thus, of the 8 investigated, 6 (75\%), work in the area of human health, one company is related to the environment sector and another company operates in the mixed segment. It is noteworthy that all companies are entirely of national capital.

The third feature is related to the size (measured by number of employees). The composition of the companies in terms of the technical staff which includes scientists and mid-level employees with some type of academic training (undergraduate and graduate) in production and management. To evaluate the company size, it was used SEBRAE (2006) criteria of classification according to employment. Accordingly, companies with up to 19 employees are considered micro enterprises; with 20 to 99 employees, small businesses, companies with 100 to 499, medium - businesses and those over 499 employees are considered large. The size of the bio companies could also have been calculated from the amount of their annual turnover. However, because this is information would involve the assessment of monetary and / or financial resources that would find resistance in collection, the classification by number of employees was preferred.

Following, therefore, the criteria of employees number, it has been observed that of the eight companies surveyed, four (E2, E3, E5 and E6), or 50\%, are characterized as micro businesses with 5, 12, 2 and 4 employees, respectively. Three companies (EI, E7 and E8), or (37.5\%), are characterized as being small, with 32,76 and 60 employees, respectively, and only one (E4), or $12.5 \%$, is characterized as a medium-sized company with 122 employees. The latter, besides being the only midsize in the set, is the oldest in the market, with 38 years.

\subsection{Technological efforts of the companies}

Initially, the ways in which the internal R\&D activities are carried out by companies are assessed. It is noticed that, of the eight companies, half (EI, E3, E7 and E8) does not have R\&D departments. Two companies (E2 and E4), have structured R\&D departments and the two other companies (E5 and E6) have semi-structured R \& D departments.

The expenditure on internal R\&D relative to revenues is presented in Table I, where it can be observed that of the eight companies surveyed, only three (E2, E4 and E5), have invested on average $10 \%, 5 \%$ and $10 \%$ respectively of their revenues in such activities in the reference period. The other five companies (EI, E3, E6, E7, E8) have not invested percentages of revenues in R\&D.

\begin{tabular}{|l|cccccccc|}
\hline \multicolumn{1}{|c|}{ Companies } & E 1 & E2 & E3 & E4 & E5 & E6 & E7 & E8 \\
\hline Expenditures on R \& D (\%) & 0 & 10 & 0 & 5 & 10 & 0 & 0 & 0 \\
\hline (\%) of expenditure on internal R \& D to revenue & 0 & & & & & & & \\
\hline
\end{tabular}

Table I: Expenditure on internal R\&D to revenue (average 2006-2008) 
In Table 2 it is evidenced that three companies (E2, E4 and E6) have R\&D professionals and overall the number of engineers and scientists is higher than the number of midlevel technicians. Only E2 and E4 have presented their R\&D as structured department. In fact E6 has not used percentage of revenues in R\&D, but have four engineers/ scientists who perform semi-structured R\&D. Thirteen employees are R\&D related-people by three companies, with an average R\&D employment of 4.3 person.

\begin{tabular}{|l|ccccccccc|}
\hline \hline Companies & E 1 & E2 & E 3 & E4 & E 5 & E6 & E 7 & E 8 \\
\hline N umber of scientists and engineers in R \& D & 0 & 2 & 0 & 4 & 0 & 4 & 0 & 0 \\
Number of mid-level technicians in R \& D & 0 & 1 & 0 & 2 & 0 & 0 & 0 & 0 \\
\hline
\end{tabular}

Table 2: Number of employees working in R\&D

Table 3 shows that R\&D spending along companies is diverse in terms of product or process innovation. Thus companies E2 and E4 have dedicated more expending on product innovations, reported to represent $60 \%, 95 \%$, as compared with the percentage of R\&D expenditure on process innovations of $40 \%, 5 \%$ respectively. If in company E2 the distribution of product/ process innovation is more balanced, in company E4 the distribution is strongly oriented to product innovation (95\%) and weakly oriented to process innovation (5\%). Company E5 on the other hand has dedicated much more expenditure on process innovation (70\%) than on product innovation (30\%). E6 has R\&D employees, but has not informed the orientation to product or process innovation.

\begin{tabular}{|l|cccccccc|}
\hline \multicolumn{1}{|c|}{ Companies } & E 1 & E2 & E 3 & E4 & E5 & E 6 & E 7 & E8 \\
\hline $\begin{array}{l}\text { Products and Processes } \\
\text { (\%) of R\&D expenditure oriented to product innovations }\end{array}$ & 0 & 60 & 0 & 95 & 30 & 0 & 0 & 0 \\
$\begin{array}{l}\text { (\%)of R\&D expenditure oriented to process innovations } \\
\text { (\%) }\end{array}$ & 0 & 40 & 0 & 5 & 70 & 0 & 0 & 0 \\
\hline
\end{tabular}

Table 3: Expenditures on R\&D - orientation to product or process innovations

Table 4 shows the number and frequency with which companies use different external technology sources for developing technologically new or improved products and processes. 


\begin{tabular}{|l|c|c|c|}
\hline $\begin{array}{c}\text { Frequency } \\
\text { of } \\
\text { occurrence }\end{array}$ & $\begin{array}{c}\text { Purchase or licensing } \\
\text { of new technologies } \\
\text { developed by other } \\
\text { companies }\end{array}$ & $\begin{array}{c}\text { Hiring companies, } \\
\text { universities and } \\
\text { research centers to } \\
\text { develop product and } \\
\text { process technologies }\end{array}$ & $\begin{array}{c}\text { Strategic alliances with } \\
\text { research centers, } \\
\text { universities and } \\
\text { companies to develop } \\
\text { products and processes } \\
\text { which are technologically } \\
\text { new or improved. }\end{array}$ \\
\hline Very high & 1 & & \\
\hline High & & 3 & \\
\hline M edium & & & \\
\hline Low & 1 & 2 & 1 \\
\hline V ery L ow & 6 & 3 & 7 \\
\hline Does not apply & & & \\
\hline
\end{tabular}

Table 4: Number of companies and frequency of use of external sources for technology acquisition to develop products and processes which are technologically new or improved (average 2006-2008)/ Very high = the company does this constantly, High = twice a year; Average $=$ once a year, Low $=$ twice in the last three years, Very Low $=$ once in the last three years, does not apply to the company.

It can be seen in Table 4 that the most important external sources for technology acquisition are companies, universities and research centers, as five companies have used these sources, three with a high frequency and two with a very low frequency.

Other external sources of technology and knowledge acquisition have very low frequency or do not apply for purchase or licensing ( 7 out of 8 companies) and the same happens to strategic alliances with research centers, universities and other companies (8 out of 8 companies).
In relation to strategic alliances formed for the development of technologically new or enhanced products, Table 5 shows that the bio companies, in general, have a fragmented framework of alliances. These relationships are low in frequency: for customer (2 out of 8 ), suppliers (6 out of 8 ), university research centers (6 out of 8 ) or international companies (7 out of 8 ). Only three cases of high frequency of relationships were observed for bio companies: with suppliers, with university or research centers, with international companies.

\begin{tabular}{|l|c|c|c|c|c|}
\hline $\begin{array}{l}\text { Frequency } \\
\text { of } \\
\text { occurrence }\end{array}$ & $\begin{array}{c}\text { With } \\
\text { clients }\end{array}$ & $\begin{array}{c}\text { With } \\
\text { Suppliers }\end{array}$ & $\begin{array}{c}\text { With } \\
\text { University/ } \\
\text { Research } \\
\text { Centers }\end{array}$ & $\begin{array}{c}\text { With other } \\
\text { national } \\
\text { companies }\end{array}$ & $\begin{array}{c}\text { With intern. } \\
\text { companies }\end{array}$ \\
\hline Very High & 0 & 0 & 0 & 0 & 1 \\
\hline High & 0 & 1 & 1 & 0 & 0 \\
\hline M edium & 1 & 1 & 1 & 1 & 0 \\
\hline Low & 0 & 1 & 1 & 1 & 1 \\
\hline Very Low & 2 & 2 & 3 & 3 & 2 \\
\hline Does not apply & 5 & 3 & 2 & 3 & 4 \\
\hline
\end{tabular}

Table 5: Number of companies and frequency of strategic alliances for the development of new or enhanced products and processes/ Very high = the company does this constantly, High = twice a year; Average = once a year, Low = twice in the last three years, Very Low $=$ once in the last three years, does not apply to the company. 
Also in Table 6, very low frequency or absence of strategic alliances to develop new or enhanced products and processes is observed with customers, suppliers, research centers and universities, other domestic companies and international companies.

\begin{tabular}{|l|c|c|c|c|c|}
\hline $\begin{array}{c}\text { Frequency } \\
\text { of } \\
\text { occurrence }\end{array}$ & $\begin{array}{c}\text { With } \\
\text { clients }\end{array}$ & $\begin{array}{c}\text { With } \\
\text { Suppliers }\end{array}$ & $\begin{array}{c}\text { With } \\
\text { University/ } \\
\text { Research } \\
\text { Centers }\end{array}$ & $\begin{array}{c}\text { With other } \\
\text { national } \\
\text { companies }\end{array}$ & $\begin{array}{c}\text { W ith intern. } \\
\text { companies }\end{array}$ \\
\hline Very High & 0 & 0 & 0 & 0 & 0 \\
\hline High & 0 & 0 & 1 & 0 & 0 \\
\hline M edium & 0 & 1 & 1 & 0 & 0 \\
\hline Low & 0 & 2 & 0 & 2 & 0 \\
\hline Very Low & 1 & 2 & 4 & 4 & 2 \\
\hline Does not apply & 7 & 3 & 2 & 2 & 6 \\
\hline
\end{tabular}

Table 6: Number of companies and frequency of strategic alliances for the development of new or enhanced products and processes/ Very high = the company does this constantly, High = twice a year;Average = once a year, Low = twice in the last three years, Very Low $=$ once in the last three years, does not apply to the company.

To conclude the analysis of technological efforts expended by the eight companies, the data obtained shows that the expenditures with patents in the reference period are missing ( 8 out of 8 companies have not informed expends on patents). It is worth noting that the company (E6) has registered one patent (shown in Table 9, next), but this case has not reported the average spending.

\subsection{Innovative Performance of the studied companies}

In Tables 7, 8 and 9, the results for the innovative performance of the eight bio companies are presented concerning their innovations in products and processes during the period of 2006 to 2008.

From Table 7, one can see that the majority of bio companies (six) did not release any significant new products in the market. Only two companies (E2 and E4) have released 2 and 4 products, respectively, in the reference period. When it comes to incremental product innovation, these numbers are further reduced. In this modality the same two companies were responsible for the development and launch of 2 technologically improved products in the reference period.

\section{Product innovations}

$\begin{array}{llllllll}E 1 & E 2 & E 3 & E 4 & E 5 & E 6 & E 7 & E 8\end{array}$

N umber of significant new innovations

$\begin{array}{llllllll}0 & 2 & 0 & 4 & 0 & 0 & 0 & 0\end{array}$

N umber of incremental innovations

$\begin{array}{llllllll}0 & 2 & 0 & 2 & 0 & 0 & 0 & 0\end{array}$

Table 7: Product innovations - 2006 to 2008 
In relation to significant new and incremental process innovations it can be observed in Table 8, that of the eight companies, only one (E4) stood out with ten cases of the first type, and more than 50 cases of the second type. Incremental process innovation was also observed in (E2), with only two cases.

\begin{tabular}{|lcccccccc|}
\hline \multicolumn{1}{|c}{ Processinnovations } & E1 & E2 & E3 & E4 & E5 & E6 & E7 & E8 \\
\hline N umber of significant new innovations & 0 & 0 & 0 & 10 & 0 & 0 & 0 & 0 \\
N umber of incremental innovations & 0 & 2 & 0 & $>50$ & 0 & 0 & 0 & 0 \\
\hline
\end{tabular}

Table 8: Innovation in processes - 2006 to 2008

When comparing Table 8 above to Table 3, previously presented, it can be observed that strategies pursued by companies E2, E4 and E5 are not working well or are inconsistent in effects. In Table 3 is shown that E2 and E4 dedicate more resources to products than to processes, particularly E4 ( $95 \%$ to products and $5 \%$ to process innovation). In Table 8 , E4 is obtaining much more results in processes than in products. On the other hand, in Table 3, E5, with semistructured R\&D pursues strategy of $70 \%$ expenditures allocated to process innovation and $30 \%$ to product innovation and is not obtaining any results at all in Table 8 .
Concerning the number of registered patents, in Table 9 is shown that only two companies, E5 and E6, had patent applications. Both have semi-structured R\&D departments and deposited one patent application each from 2006 to 2008. The case of E5 seems inconsistent as no product or process innovation is indicated for the reference period (Tables 7 and 8) and the company has one registered patent for the period (perhaps due to results obtained previously to the reference period). Although companies E2 and E4 have structured R\&D departments, they had not registered product patents in 2006 to 2008 .

\begin{tabular}{|lcccccccc|}
\hline \multicolumn{1}{|c|}{ Product patents } & E1 & E2 & E3 & E4 & E5 & E6 & E7 & E8 \\
\hline Number of patents & 0 & 0 & 0 & 0 & 1 & 1 & 0 & 0 \\
\hline
\end{tabular}

Table 9: Number of product patents registered - 2006 to 2008

Table 10 shows portions of the revenue derived from significant new products or incremented products internally developed by company (unlicensed) and marketed from 2006 to 2008. The results show that of the eight companies surveyed, two (E2 and E4) reached $10 \%$ and $7 \%$, of the revenues of technologically new or improved products or as result of launching new or improved technology. As expenditures by these companies (E2 and E4), were high as shown earlier in Table 3, it can be noticed that they have not reached an excellent level of performance.

\begin{tabular}{|lllllllll|}
\hline \multicolumn{1}{|c|}{ Percentage of revenues } & E1 & E2 & E3 & E4 & E5 & E6 & E7 & E8 \\
\hline $\begin{array}{l}\text { (\%) Share of revenues derived from new products or } \\
\text { improved products marketed } \\
\text { in the period }\end{array}$ & 0 & 10 & 0 & 7 & 0 & 0 & 0 & 0 \\
\hline
\end{tabular}

Table 10: Percentage of revenues - 2006 to 2008 


\section{Discussion}

The results obtained in the study of the companies are organized in three blocks of objectives (company profile, technological efforts and innovative performance). The discussion here presented follows the same order.

The first block, characterized the bio companies located in Belo Horizonte, in three respects: age, predominant segments of activity and size (in terms of number of employees).

The second block described technological efforts spent over the years 2006 to 2008 by the companies. Within this context, the study allowed to analyze the structure of R\&D departments of the eight companies. It was observed that four have no R\&D department; two have formally structured R\&D and other two have less formal (semi-structured) R\&D.

Companies E2, E4 and E6 have formalized departments and employees of different skills (engineers, scientists or technical level) dedicated to R\&D activities. The five remaining companies showed no R\&D staff, indicating the absence of R\&D formalization. Only three companies invested in products and process innovation R\&D.

According to the literature review, the degree of the R\&D structuring usually does not follow any clearly defined standard, nor is clear the relationship between R\&D structure and business growth measured by revenue growth (Pine, 2006). The literature also notes that the business size (measured by number of employees) may have relevance in the structuring of the R\&D, with large companies tending to have structured $R \& D$ and small companies presenting unstructured R\&D (Rieg and Alves Filho, 2003, Pinho, 2006). The bio companies of Belo Horizonte showed variability of situations with predominance of low-structuring R\&D.

Tables 4, 5 and 6 complete information on unstructured R\&D performing, indicating effective use or not of external sources for technological development of products and processes (licensing, and strategic alliances with customers and suppliers, research centers and universities) indicating little or no use of licensing, purchase of technology, hiring companies or strategic alliances.
It is noted that the firms behavior here analyzed is quantitatively different from that presented in the research and Rieg and Alves Filho (2003), which was used as the basis for the present study. Their research data covers enterprises of the medical and hospital sector located in São Carlos (SP). For this sector, only $25 \%$ of firms had structured R\&D and most of them (58\%) performed with semi-structured R\&D, more frequently using purchase or licensing of new technologies developed by other companies. The companies surveyed here have opted for hiring companies and sourcing universities and research centers to develop technologies for product and process.

As for expenses related to internal R\&D, it was observed that all bio companies spent substantial efforts in both technological innovation and in improving its products and processes in 2006-2008. This concentration of efforts in internal R\&D technological activities is quite similar to the behavior of companies in the healthcare. Just for reference, whereas the companies surveyed here the average R\&D investment relative to revenues is $8.33 \%$, in the medical and hospital sector, this percentage is $8 \%$. Compared to other sectors in Brazil, this percentage is much higher than that found in the study by Arruda, et al., (2006), whose investment on average is $0.64 \%$ of their turnover on innovation, both for the improvement and acquisition of products.

It is emphasized that the comparisons set forth herein should be seen with caution, only as a reference for what they represent for the whole of Brazil, considering that the methods of calculating the percentage of investments are not fully compatible with each other. The methodology used here is based on the methodology of SOBEET and Rieg and Alves Filho (2003) and is different from that of Arruda, et al., (2006).

It was also evidenced that the technological efforts surveyed focused on internal R\&D, turning primarily into the development of new products rather than to develop new processes. Thus, of the four companies that performed some kind of R\&D, two companies allocated more than $60 \%$ of their spending to product innovations.

Analyzing the cost of acquisition from outside sources, it was found that the companies, have not invested, or invested little in technology acquisition from external 
sources and invested more in activities related to internal R\&D. Furthermore, strategic alliances with research centers, universities and companies were the less used resources to innovation by the companies.

With regard to strategic alliances to develop technologically enhanced products and processes, research centers and universities appeared as the main partners of the companies, however, with a frequency ranging from very low and very high. This result corroborates with Rieg and Alves Filho (2003) mention that companies have often been unable to guide investment associated with a complex set of resources and expertise for this purpose. Because the results of internal $R \& D$ are often uncertain, companies often seek outside sources of technology and the hiring of universities and research centers.

The third and last block (Tables 7, 8, 9 and 10), discusses the innovative performance, the results of efforts related to technological innovations in product and process commercially viable made by companies. It was found that of the eight companies studied, two companies (E2 and E4) have 2 to 4 significant new products from 2006 to 2008. The same companies were each responsible for launching two innovative products of incremental nature. It is necessary to remember that these companies have structured R\&D.

As for patent applications, it was found that the number of patents related to the eight surveyed companies is very shy, only two patent applications were filed at the INPI (National Institute of Industrial Property) by two companies (E5 and E6). So, little was invested in patent protection for new products, especially if one considers the new Innovation Law approved in December 2004, which regulates tax incentives for R\&D activities and technological innovation, giving a big boost for this sector (Arruda, et al., 2006).

As for process innovations, significant new and incremental innovation occurred to a minority part of the studied companies. Only one company (E4) stood out with more than 50 cases of incremental process innovation Although the emphasis of this company on internal R\&D had the potential of generating a relatively high number of significant new process innovations, it was observed that, most process innovations were of incremental nature. Finishing the discussion of the research findings, it was observed that no company, the eight investigated, spent with patents in relation to revenues.

\section{Conclusion}

The results obtained in the study provided general information related to the profile of the bio companies located in Belo Horizonte, thus achieving the first objective. Although all companies are located in a geographical region, knowing their characteristics enabled better understanding their profile, according to the life cycle, the size and predominant economic activities, contributing to greater understanding of this sector.

As for the second objective, the results helped to characterize the profile and behavior of the surveyed companies in terms of the technological efforts expended by them: (a) half of surveyed companies have structured R\&D (i.e., have its own integrated research) or semistructured (perform R\&D internal activities sporadically), (b) the average number of people working in companies with structured and semi-structured R\&D departments is 4,3 employees, but considering all companies, total employment was 343 people, of which only $3.8 \%$, of total employed personal is really dedicated to R\&D; (c) the technological efforts of firms surveyed were predominately focused on internal R\&D, more oriented to the development of new products than to develop new processes (though results have shown larger number of incremental process innovation); (e) when it comes to spending on internal R\&D relative to revenues, these companies have spent significant technological effort ( $8.33 \%$ in the last three years), as compared to other Brazilian companies (estimated at $0.64 \%$ in 2006; (f) as for external sources of technology acquisition, the main mechanisms used are contracting other companies, universities and research centers; ( $g$ ) no company has spent on patents in relation to revenues.

The third objective, the goal was also met but the obtained results are thin. The innovative performance in relation to products and processes carried out by the surveyed companies (2006-2008), presented the following picture: (a) Only two companies surveyed (25\%) innovated in the last three years, (b) of the companies that innovated, none obtained or registered patents, (c) six significant new product innovations were identified within the base period, representing an average of 2 new product innovation per year, which represents an average of 0.25 new innovation/ year per surveyed company; (d) when it comes to product incremental innovations, the amount is still lower (4 improved products), within the three-year 
period, or an average of 1.3 improved products per year, and an average of 0,16 incremental innovation / year, per surveyed company; (e) significant new process innovation occurred in 10 cases in only one company (E4), for the surveyed set this represents an average of 3.3 significant new process innovation per year, and an average of 0,4 significant new process innovation per year/ per surveyed company; (f) as for incremental process innovation, again only one company had presented 50 innovations, the average of 16.6 innovation per year and 2.08 incremental process innovation/ year, per surveyed company; and only two companies have each registered one patent application within the past three years, (g) to the two companies $(25 \%)$ that have indeed innovated in the set of surveyed companies, within the past three years, about $10 \%$ and $7 \%$ of its revenues are the result of releasing new or improved technology.

Overall, the results obtained for the three settled objectives provide partial picture (as only eight companies were surveyed) that meets the general purpose of the study, namely, allowing better understand of the behavior of bio companies located in Belo Horizonte - MG, as little was known about their R\&D configuration and virtually nothing was known about their innovative performance in terms of technological effort.

As for the response to the research question that guided this study, we can infer that the companies surveyed in Belo Horizonte, the minority (three) spent relatively high technological efforts with internal R\&D relative to revenues (2006-2008) and for innovation products and processes, but their innovative performances were rather thin, i.e., not achieved a significant breakthrough. Thus, the companies investigated here cannot be considered innovative.

\section{References}

ARRUDA, M., Vermulm R., Hollanda, S. (2006). Inovação tecnológica no Brasil: a indústria em busca da competitividade global. ANPEI, São Paulo.

BARBIERI, J. C. (2003). Organizações inovadoras: estudos e casos brasileiros. In: Barbieri, J. C., Álvares, A. C. T. Inovações nas organizações empresariais. RJ: FGV, Rio de Janeiro, pp.4I-63.

BIO. (2008). - Biotechnology Industry Organization. Biotech Tools in Research and Development http://bio.org/speeches/pubs/er/biotechtools.asp [Acessed September 28, 2008].

COHEN, W. M., Levinthal, D. A. (1989). Innovation and learning: the two faces of R\&D. The

Economic Journal, v. 99 (397) 569-596.

COLLIS, J., Hussey, R. (2005). Pesquisa em administração: um guia prático para alunos de graduação e pós-graduação. (2a. ed.). Ed. Bookman, Porto Alegre.

CORREIA, P. C., Nunes, B. E. C., Mandelli, I. A. M., Nicoluci, M. V. (2005). A inovação e a tecnologia a serviço de novos ganhos concorrenciais entre empresas. RACRE Revista de Administração v. 5 (9), 17-34.

ERNST \& YOUNG. (2000). The economic contributions of the biotechnology industry to the U.S. economy. Prepared for the Biotechnology Industry Organization by Ernst \& Young Economics Consulting and Quantitative Analysis. http/l:www.bio.org/speeches/pubs/ernstyoung. pdf [Acessed September 26, 2008].

ERNST \& YOUNG. (201I). Beyond borders. Global Biotechnology Report, 25th Anniversary Edition. http:// www.ey.com/Publication/vwLUAssets/Beyond_Borders global_biotechnology_report_20II/\$FILE/Beyond\%20 borders 25th\%20-\%20Global\%20biotechnology\%20report\%2020II.pdf [Accessed September 28, 20II].

FIATES, J. E. A., Schneider, C. A. (1998). Caracterização e gestão do sistema de inovação tecnológica num centro de tecnologia. Anais do XX Simpósio de Gestão da Inovação Tecnológica, São Paulo, SP, Brasil. 
FUNDAÇÃO BIOMINAS. (2007). Estudo de empresas de biotecnologia do Brasil. http://win.fundaçãobiominas.or g.br/estudobio/estudol [Accessed June 16, 2008].

FUNDAÇÃO BIOMINAS. (2009). Estudo das empresas de biociências Brasil 2009. http://win.biominas.org.br / biominas 2008/File/estudo\%20setorial\%20site.pdf [Acessed September 28, 20II].

HITT, A. M., Ireland, R. D., Hoskisson, R. E. (2005). Administração estratégica. Ed. Thompson, São Paulo.

IBGE. (2008). Pesquisa de Inovação Tecnológica - PINTEC 2008. Rio de Janeiro 2010. http://www.pintec.lbge. gov .br/downloads/PUBLICACAO/Publicacao\%20PINTEC\%202008.pdf [Acessed September, 18, 20II].

JEANNET, J. P., Hennessey, H. D. (1992). Global marketing strategies. (2a. ed.). Houghton Mifflin Company, Boston.

LAMBE, C. J., Spekman, R. E. (1997). Alliances, external technology acquisition, and discontinuous technological change. Journal Prod. Innovation Management, v.14 (2), I02-II6.

OECD (2005). Manual de Oslo. Proposta de diretrizes para coleta e interpretação de dados sobre inovação tecnológica. OECD, FINEP (trad. Portuguese). http://www. finep.gov.br/imprensa/sala_imprensa/manual_de_oslo. pdf [Acessed September 30, 20II].

PAVITT, K. (1990). The international patterns and determinants of technological activities. In: Cozzens, S. E.; Healey, P.; Rip, A.; Ziman, J. (Editors). The Research System in Transition. Kluwer Academic Publishers, Dordrecht, The Netherlands. pp. 89-I0I.

PINHO, M. Relatório Setorial Final. Brasília: FINEP 2006. http://www.finep.gov.br/PortalDPP/relatorio_setorial final/relatorio setorial final impressao.asp?!st_setor $=8$ [Acessed September 20, 2008].

PISANO, G. P. (2006). Can Science be a Business? Lessons from Biotech. Harvard Business Review. October, II4- 125.

PORTER, M. E. (1989). Estratégia competitiva: técnicas para análise de indústrias e da concorrência. Ed. Campus, 13.a reimpr., Rio de Janeiro.
QUADROS, R. C., Furtado, A., Bernardes, R., Franco, E. (1999). Technological innovation in Brazilian industry: an assessment based on the São Paulo innovation survey. In: International Conference on Technology Policy and Innovation. (3a. ed.). Austin.

RIEG, D. L., Alves Filho, A. G. (2003). Esforço tecnológico e desempenho inovador das empresas do setor médicohospitalar localizadas em São Carlos, SP. Revista Gestão \& Produção, v. 10(3), 293-310.

SANTANA, L. M., Hasenclever, L., Mello, J. M. C. (2003). Capacitação tecnológica e competitividade na petroquímica brasileira nos anos 1990: o caso de Camaçari - BA. Revista Brasileira de Inovação, v. 2 (I), I47-177.

SCHUMPETER, J. A. (197I). La inestabilidad del capitalismo. In: Rosemberg, N. (Org.). Economía del cambio tecnológico. Fondo de Cultura Económica, México.

SEBRAE. (2006). Serviço Brasileiro de Apoio às Micro e Pequenas Empresas. Negócios da biotecnologia. Boletim do empreendedor. http://www.biblioteca.sebrae.com.br/ bds/BDS.nsf/ae6caac3adfd6|I48325746300476e68/\$File/ N T000389FA.pdf [Acessed September 18, 2008].

SOBEET. (2000). Sociedade Brasileira de Estudos de Empresas Transacionais e da Globalização Econômica. Comportamento Tecnológico das Indústrias Transacionais em Operação no Brasil. (Coord. Matesco, V.R), Março, Suplemento Especial da Conjuntura Econômica, São Paulo, 34 p.

SUZIGAN, W. (1992). A indústria brasileira após uma década de estagnação: questões para política industrial. Revista Economia \& Sociedade, IE-Unicamp, Campinas, v. I, 89-109.

ZAHRA, S. A., Bogner, W. C. (1999). Technology strategy and software new ventures' performance: exploring the moderating effect of the competitive environment. Journal of Business Venturing, v. I5 (2), I35-I73. 
J. Technol. Manag. Innov. 20II,Volume 6, Issue 4 